\title{
İngilizce Yazma Becerisini Kazanma Sürecinde Karşılaşılan Sorunların Yazma Becerisi Dil Öğrenme Stratejileri İle Giderilmesi *
}

\author{
Emine Akkaş Baysal ${ }^{1}$
}

\author{
Gürbüz Ocak²
}

\author{
Type/Tür: \\ Research/Araştırma \\ Received/Geliş Tarihi: February \\ 12/ 12 Şubat 2020 \\ Accepted/Kabul Tarihi: \\ November 10/ 10 Kasım 2020 \\ Page numbers/Sayfa No: 77-100 \\ Corresponding \\ Author/İletişimden Sorumlu \\ Yazar: \\ akkasemine85@hotmail.com
}

\section{$\checkmark$ iThenticate}

This paper was checked for plagiarism using iThenticate during the preview process and before publication. / Bu çalışma ön inceleme sürecinde ve yayımlanmadan önce iThenticate yazılımı ile taranmıştır.

\section{Copyright $(2017$ by}

Cumhuriyet University, Faculty of Education. All rights reserved.

\begin{abstract}
Öz
Yabancı dil öğrenen bireyler için yazma becerisi, hedef dilin öğrenilmesi ve işlevsel hale getirilmesi için en temel becerilerden birisidir. Yazma becerisi ile öğrenciler hem hedef dilin dil bilgisi kuralların hem de kelime bilgisini bir arada kullanırken diğer taraftan bunlar arasında anlamlı ilişkiler kurarak bir bütün oluşturmaya çalışırlar. Bu bağlamda, çalışmanın amacı ortaöğretim 9. sinıfta öğrenim gören öğrencilerin İngilizce yazma becerisini kazanma sürecinde karşılaştıkları problemlerin, onlara yazma becerisi dil öğrenme stratejilerini nasıl kullanacakları öğretilerek ortadan kaldırılmasıdır. Araştırma, nitel araştırma yöntemleri arasında yer alan eylem araştırması ile gerçekleştirilmiştir. Çalışma grubunu, 2018-2019 eğitim öğretim yılında Afyonkarahisar il merkezindeki bir lisede öğrenimlerine devam eden 38 öğrenci oluşturmaktadır. Veriler, araştırmacılar tarafından geliştirilen yarı yapılandırılmış görüşme formu, gözlem formu, araştırmacı-uygulayıcı ve öğrenci günlükleri ile toplanmıştır. Verilerin analizinde betimsel analiz kullanılmıştır. Elde edilen veriler, yazma becerisi dil öğrenme stratejilerini kullanmaya başlayan öğrencilerin yazma etkinliklerine çok daha motivasyonu yüksek bir şeklide başladığını ve bu motivasyonun yazma sürecini olumlu anlamda etkilediğini göstermektedir. Ayrıca, yazma etkinliğini yazma stratejileri kullanarak yapan öğrencilerin yazma esnasında ne yapacaklarını çok daha iyi bildikleri için etkinlikleri çok daha doğru yaptıkları gözlemlenmiştir.
\end{abstract}

Anahtar Kelimeler: Yazma öncesi, yazma esnası, yazma sonrası, strateji, eylem araştırması

\section{Suggested APA Citation/Önerilen APA Atıf Biçimi:}

Akkaş Baysal, E., \& Ocak, G. (2020). İngilizce yazma becerisini kazanma sürecinde karşılaşılan sorunların yazma becerisi dil öğrenme stratejileri ile giderilmesi. Cumhuriyet International Journal of Education, 10(1), 77-100. http://dx.doi.org/10.30703/cije.688670

\footnotetext{
*Bu çalışma “Dil Öğrenme Stratejileri Öğretim Programı Taslağının Hazırlanması, Uygulanması ve Değerlendirilmesi" başlıklı doktora tez çalışmasından türetilmiştir.

${ }^{1}$ Dr. Öğr. Üyesi, Afyon Kocatepe Üniversitesi, Sandıklı Uygulamalı Bilimler Yüksekokulu, Afyon/Türkiye Asst. Prof. Dr., Afyon Kocatepe University, Sandıklı School of Applied Disciplines, Afyon/Turkey e-mail: akkasemine85@hotmail.com ORCID ID: 0000-0002-5711-0847

2 Prof. Dr., Afyon Kocatepe Üniversitesi, Eğitim Fakültesi, Eğitim Programları ve Öğretim Anabilim Dalı, Afyon/Türkiye

Prof. Dr., Afyon Kocatepe University, Faculty of Education, Department of Curriculum and Instruction, Afyon/Turkey e-mail: gurbuzocak@gmail.com ORCID ID: 0000-0001-8568-0364
} 


\title{
Eliminating the Problems Encountered in the Process of Gaining English Writing Skills with Writing Skills Language Learning Strategies
}

\begin{abstract}
For individuals learning foreign languages, writing skill is one of the basic skills for learning and functionalizing the target language. With the ability to write, students use both the grammar rules and vocabulary of the target language together, and try to form a whole by establishing meaningful relationships between them. In this context, the aim of this study is to eliminate the problems that the 9th grade students faced in the process of gaining English writing skills by teaching them how to use language learning strategies. The research was carried out with the action research. The study group of the research consists of 38 high school students in Afyonkarahisar studying in the 2018-2019 academic year. The research data were collected by a semistructured interview form, an observation form, researcher-practitioner and student diaries. The data were collected during the treatment process. Descriptive analysis was used in the analysis of data. The data obtained from the diaries, the interview and observation forms show that students using language learning strategies started writing activities in a much more motivated way and this motivation positively affected the writing process. In addition, it was observed that the students who completed the writing tasks using writing strategies did the activities much more accurately because they knew what to do during the writing activity much better.
\end{abstract}

Keywords: Pre-writing, during writing, post-writing, strategies, action research

\section{Giriş}

Bilişsel kuramlar ve öğrencinin merkezde olduğu yaklaşımlarla birlikte yabancı dil öğretiminde de öğrenen merkezli tasarımlar ortaya çıkmıştır. Bu değişikliğe paralel olarak öğrenenlerin bireysel özellikleri daha fazla önem kazanmıştır. Başarılı olan öğrencilerin nasıl başarılı oldukları ve izledikleri yol ile başarısız olan öğrencilerin başarısızlık nedenlerine ilişkin merak ve ilgi giderek artmaktadır. Öğrencilerin, başarı ve öğretme-öğrenme durumlarını önemli ölçüde etkileyen zekâ, yaş, cinsiyet, öğrenme stili vb. gibi pek çok unsur vardır. Son zamanlarda bunlar arasından en dikkat çekenlerden biri de dil öğrenme stratejileridir. Dil öğrenme stratejileri, öğrencilerin hangi stratejileri daha sık tercih ettikleri ve iyi bir öğrenenin özelliklerinin neler olduğu birçok araştırmanın konusu olmuştur (Berry, 2007; Cohen, 1990; Nisbet ve Shucksmith, 1986 O'Malley ve Chamot, 1990; Oxford, 1990; Rubin, 1987).

Öğrenme hakkındaki en önemli konulardan birisi öğrencilerin nasıl öğrendikleri olmuştur. Duffy (1982), öğrenmenin gizli algoritmasının stratejiler altında yattığını ifade etmiştir. Oxford (1990), stratejilerin özellikle yabancı bir dili öğrenmede önemli olduğunu çünkü öğrenme stratejilerinin iletişimsel yeterliği geliştirmek için gerekli olan aktif ve kendi kendini yöneten öğrenenler yetiştirmede iyi bir araç olduğunu belirtmiştir. Çalışmalar, uygun dil öğrenme stratejileri kullanıldığında bireylerin kendine olan güvenlerinin arttığını ve yeterliği yüksek bireylerin yetişmesine olanak tanıdığını göstermiştir (Berry, 2007; Cohen, 1990; Duffy, 1982; Nisbet ve Shucksmith, 1986; O'Malley ve Chamot, 1990; Oxford, 1990; Rubin, 1987). Dil öğrenme stratejileri, yabancı dil öğrenme gayretinde olan 
öğrencilerin kendi öğrenme sorumluluklarını alarak, bu süreci yönetmeleri, öğrenmelerini daha etkili, verimli, hızlı hale getirmek amacıyla attıkları adımlardır.

Dil öğrenme stratejileri alanında yapılan öncü çalışmaların Rubin (1975) ve Stern (1975) gibi araştırmacılar ile 1970'li yılların ortalarında başladı̆̆ı kabul edilir. Her ne kadar aradan çok uzun zaman geçmiş olsa da yapılan çalışmalarda ortak bir tanımın olmadığ1 (O'Malley, Chamot, Stewner-Manzanares, Kupper ve Russo, 1985) dil öğrenme stratejilerinin farklı şekillerde tanımlandığ1 görülmektedir. Rubin (1975), dil öğrenme stratejilerinin, öğrenenin bilgi edinmek için kullandığı araçlar ya da teknikler olduğunu ifade etmiştir. Öğrenme stratejileri, öğrenenin bir öğrenme hedefini başarmak için gerçekleştirdiği bilinçli düşünce ve eylemlerdir. Stratejik öğrenenler kendi düşünmeleri ve öğrenme yaklaşımları hakkında üst-bilişsel bilgiye sahiptirler (Chamot, 2004). Dil öğrenme stratejilerinin tanımlarında olan farklılıklar, dil öğrenme stratejilerinin doğası gereğidir. Ancak tanımların tamamı dil öğrenenlerin dil öğrenme süreçlerini daha etkili, daha hızlı, verimli hale getirmeye odaklanmaktadır. Wenden (1987) ise, strateji kavramını, ikinci dilin öğrenilmesinin düzenlenmesi için öğrencilerin kullandığ1 dil öğrenme davranışı olarak tanımlamıştır. Weinstein ve Mayer'e (1986) göre, dil öğrenme stratejileri öğrenme sürecinde gerçekleştirilen ve bu süreci etkili kılması umulan davranış ve düşüncelerdir. Oxford (1990), strateji kavramını, bir amacın gerçekleştirilmesi için kullanılan plan, adım ya da bilinçli eylemler olarak tanımlamıştır. Dil öğrenme stratejileri öğrencinin dil öğrenmeyi daha eğlenceli, daha kendine yönelik ve daha başarılı, daha kolay, daha hızlı ve yeni durumlara daha kolay aktarılabilir yapmak için kullandığı belirli eylemlerdir. Dil öğrenme stratejileri, öğrencilerin bir dil hakkındaki bilgilerini genişletmek amacıyla kullandıkları teknikler, ipuçları, taktikler, inançlar, duygular ve davranışlardır. Bu unsurların tamamı dil öğrenme sürecini etkili hale getirir ve öğrenciler açısından dil öğrenme sürecini kolaylaştırır. Hedef dilde yeterlik düzeylerinin gelişmesine katkı sağlar ve problem çözme fırsatları sunar. Bu yolla öğrenenler dile ait tüm becerilerde (okuma, yazma, dinleme, konuşma, dil bilgisi ve kelime) gelişme kaydederler (Sabria, 2016). Dil öğrenme stratejilerini kullanmak öğrenenlerin yeni öğrenme durumlarını nasıl ele alacakları, kendi çalışmalarını nasıl değerlendirecekleri, kendi başarılarından ya da başarısızlıklarından nasıl ders çıkaracakları konusunda öğrenenlere yardım eder.

Dil öğrenme sürecinde öğrenci sadece belli bir konunun temel kavramlarını ve kurallarını öğrenme gayretinde olmamalıdır. Dilin işlevsellik özelliğini yerine getirebilmek için, hedef dile ait öğrenilenlerin dilin kullanışlılığını da artırması beklenmektedir. Yabancı dili öğrenen öğrenci, dili öğrendiği süreçte sadece dilin yapılarına değil aynı zamanda hedef dilin kullanıldığı çevreye, hedef dilde sahip olduğu iletişim yetkinliğine de odaklanmalıdır. Bu pencereden bakıldığında yabancı dil öğrenme sürecinde öğrenci bilişsel bir süreçten geçmektedir. Burada önemli olan dile ait temel dil bilgisi ile kelime bilgisinin ve dört temel becerinin (dinleme, konuşma, okuma, yazma) bir bütün olarak gelişmesidir. Eş zamanlı ve bütüncül gelişimin temelinde, dil bilgisi ve kelime bilgisi ile diğer becerilerin bir araya getirilip yaşama aktarılması yatmaktadır. Bu nedenle başarılı bir şekilde yabancı dil öğrenmede, öğrencinin dil öğrenme stratejilerini bilmesi hem bu bütüncül öğrenmede hem de öğrencinin kendi öğrenme sürecini kontrol etmesinde üstbilişsel bir yapının oluşmasına katkı sağlar. 
Dil öğrenme süreci bu bağlamda ele alındığında dilin dört temel becerisinin her birinin kendi içerisinde geliştirilmesi önem arz etmektedir. Özellikle öğrenenin dil öğrenme sürecinde hedef dile ait öğrendiklerinden yola çıkarak dili üretmeye başladığı konuşma ve yazma becerileri öğrenenlerin dil yeterliği kazanmalarındaki temel iki beceridir. Bu becerilerden yazma becerisi bireylere zaman ve mekân sınırları ötesindeki insanlarla iletişim kurma becerisi sunar. Kültürün, bilginin ve fikirlerin bir nesilden diğerine transfer edilmesini sağlar. Yazma becerisinin geliştirilmesi öğrenenlerin dil akademik becerilerinin gelişmesi için oldukça gerekli bir unsur olduğundan, dil öğrenenler için son derece önemlidir. Yazma becerisi herhangi bir disiplin içerisinde bilginin üretilmesi ve dağıtılması için gerekli bir beceri olarak düşünülür. Öğrenenlerin bir dildeki akademik başarılarının değerlendirilmesi onların fikirlerini ve bilgilerini aktarabilme yeteneklerine bağlıdır (Graham ve Perin, 2007). Canagarajah (2002), yazma becerisinin beş önemli özelliğini şu şekilde açıklar: (1) yazma gerçekleri ortaya çıkarır ve yansıtır; (2) yazma becerisi belli bir yer ve zaman içerisinde okuyucu ve yazar arasında gerçekleşen sosyal iletişimsel bir aktivitedir; (3) yazma becerisi yazarın kendisini ifade etmesini ve kendi görüşlerini yansıtmasını sağlar; (4) bu beceri tarihi dinamik bir süreçtir, (5) ki bu süreç içerisinde kavramlar, tartışmalar, fikirler ve çabalar kişilerin yorumuna açıktır (akt; Raoofi, Binandeh ve Rahmani, 2017).

Dil öğrenme sürecinde öğrenilen dile ait tüm beceriler (okuma, yazma, dinleme, konuşma) göz önüne alındığında en çok problem yaşadıkları alanlardan birisi yazma becerisidir. Kustati ve Yuhardi (2014) bununla ilgili olarak, aslinda sadece dil öğrenenlerin değil dili öğretenlerin de yazma becerisini kazandırma konusunda problem yaşadıklarını ifade etmişlerdir. Öğrenciler, dil yeterlik düzeylerinin düşük olması nedeniyle yazma becerisinin gereklerini yerine getirmede problem yaşamaktadırlar. Aynı zamanda öğrencilerin İngilizce kelime, dil bilgisi, heceleme ve telaffuz gibi konularda İngilizce bilgi yeterliliğine sahip olmamaları onların yazma becerisine ilişkin ilgilerinin azalmasına neden olmaktadır (Karim, 2012). Bunlara ek olarak öğretmen de öğrencilerin yazma becerilerinin gelişiminde hangi metot, etkinlik ve dil görevlerini seçmeleri gerektiği konusunda kararsızlık yaşamaktadirlar (Yusuf, Jusoh ve Yusuf, 2019).

Dil öğrenen bireylerin yazma becerisinde problem yaşamaları büyük oranda onların hedef dilde zayıf düşünme becerilerine sahip olmasından kaynaklanmaktadır. Hedef dilde yazma pek çok öğrenen için karmaşık ve çok yönlü bir olgu olarak görülmektedir. Yine pek çok öğrenen için hedef dilde yazma ana dilde yazmaktan çok daha zordur. Bu konuya ilişkin Weigle (2005) yaptığ1 çalışmada ana dilde yazan öğrenenlerin otomatik ve hılı olduklarını, dil bilgisi ve kelime bilgisine ilişkin problem yaşamadıklarını, problem yaşadıkları noktada kısa sürede çözüm üretebildiklerini, ihtiyaç duydukları bilgiye nereden ulaşabileceklerini bildiklerini ifade ederken hedef dilde yazan aynı öğrenenlerin yazma esnasında nereye odaklanacaklarını bilmediklerini vurgulamıştır. Çalışmada hedef dilde yazmaya çalışan öğrenenlerin yeterli olmadığını, dil bilgisi ve kelime bilgisi konusunda nasıl pratik çözümler üretebileceklerine ilişkin fikirleri olmadı̆̆ını belirtmiştir. Rao (2007) ise hedef dilde yazmanın öğrencilere zor geldiğini çünkü hedef dilde yazmanın farklı dil bilgisel ve bilişsel stratejiler gerektirdiğini ve öğrenenlerin bu konuda çok fazla fikrinin olmadığını ifade etmiştir. 
Hedef dilde yazma stratejilerini kullanmanın yazma becerisini geliştirdiği pek çok araştırmacı tarafından vurgulanmıştır (Sabria, 2016; Sasaki, 2007; Wong, 2005). $\mathrm{Bu}$ araştırmalarda hedef dilde kullanılan yazma stratejileri ile öğrenenlerin yazma becerileri arasında pozitif ilişki olduğu, daha fazla yazma stratejisi kullanan öğrenenlerin yazma becerisindeki yeterliklerinin geliştiği belirtilmektedir. Sabria (2016), yazma becerisinde problem çözme stratejilerini kullanmanın başarılı bir yazar olmanın yolunu araladığını ifade etmiştir. Yine yazma becerisinde öğrenenin kendisine verilen dil görevini analiz etmesinin, taslak hazırlamasının, tekrarlar yapmasının ve hatalarını düzeltmesinin ya da düzelttirmesinin yazma becerisinde gelişme kaydetmelerine olanak tanıdığını ifade etmiştir. Öğrencilerin yazma öncesinde taslaklar hazırlamaları, bu taslakları gözden geçirerek yenilemeleri, öğrenme ortamında akranları ile işbirliği yaparak yazdıklarını düzeltmeleri yazma becerisinin gelişmesine katkı sağlar. Bu durum yazma esnasında dil öğrenme stratejilerini kullanmanın önemini ortaya koymaktadır. Yine benzer çalışmalarda (He, 2005; Nguyen ve Gu, 2013) yazma esnasında dil öğrenme stratejilerini kullanan öğrencilerin yazma becerisi akademik başarılarının ve bu konudaki yeterliklerinin geliştiği görülmektedir.

Bu bağlamda bu çalışmada Anadolu Lisesi 9. sınıfta öğrenim gören öğrencilerin İngilizce yazma becerisinde karşılaştıkları problemlerin, onlara yazma becerisi dil öğrenme stratejilerini nasıl kullanacakları öğretilerek ortadan kaldırılması amaçlanmaktadır. Araştırmada aşağıda belirtilen araştırma sorularının cevabı aranacaktır:

1-İngilizce yazma etkinliklerinde yazma becerisi dil öğrenme stratejilerini kullanmanın yazma becerisine olumlu katkıları nelerdir?

2-İngilizce yazma etkinliklerinde yazma becerisi dil öğrenme stratejilerini kullanmanin olumsuz yönleri nelerdir?

3-İngilizce yazma becerisi dil öğrenme stratejilerinin öğrencilerin yazma becerilerinin gelişimine nasıl bir katkı sağlamaktadır?

\section{Yöntem}

Araştırma, nitel araştırma yöntemleri arasında yer alan eylem araştırması yöntemiyle gerçekleştirilmiştir. Eylem araştırmaları eğitim çalışanlarının kendi okullarını, sınıflarını, eğitimsel çalışmaların ve girişimlerin geliştirilmesini ve uygulamasını, bu uygulamaların etkililiğin değerlendirilmesini eleştirel olarak ele almaktadır. Böylece eğitimsel sorunların ele alınmasında farklı bir bakış açısı sunmaktadır (Ocak ve Akkaş Baysal, 2019). Bu çalışmada İngilizce yazma becerisinde sorun yaşayan öğrencilerin yazma becerilerini geliştirmek amacıyla yazma becerisi dil öğrenme stratejilerinin öğretilmesine yer verilmiştir. Araştırma kapsamında öğrencilerle yazma becerisi dil öğrenme stratejilerinin ve yazma etkinliklerinin yer aldığ 1 toplam üç farklı etkinlik üç ayrı eylem planı ile gerçekleştirilmiştir. Dolayısıyla bu uygulamalarda eylem araştırması kullanılarak öğrencilerin yazma becerilerinin gelişimine katkı sağlamak hedeflenmiştir.

\section{Çalışma Grubu}

Araştırmanın çalışma grubu seçkisiz olmayan örnekleme yöntemlerinden amaçlı örnekleme yöntemiyle belirlenmiştir. Bu noktada yapılmak istenen derinlemesine araştırma yapabilmek için çalışmanın amacı bağlamında bilgi açısından zengin 
durumların seçmektir (Büyüköztürk, 2012). Araştırmanın çalışma grubunu, 20182019 eğitim öğretim yılında Afyonkarahisar il merkezindeki bir lisede öğrenimlerine devam eden 38 öğrenci oluşturmaktadır. Bu öğrencilerin Íngilizce yazma etkinliklerinde başarısız oldukları gözlemlenmiş ve eğitim-öğretim döneminin birinci döneminde yazma becerisine ilişkin yapılan uygulama sınavında akademik başarılarının oldukça düşük olduğu gözlemlenmiştir. Bu amaçla bu çalışma grubu araştırmaya dâhil edilmiştir. Eylem araştırmasına dâhil olan öğrencilerin özelliklerine aşağıda yer verilmiştir. Araştırmanın çalışma grubu:

- Öğrenim gördükleri okula adrese dayalı yerleştirme sistemi ile yerleştiğinden belirli bir puan aralığında değildir. Ancak 1. eğitim-öğretim döneminin başında yapılan İngilizce seviye belirleme sınavı sonuçları öğrencilerin İngilizce akademik başarı düzeylerinin birbirlerine oldukça yakın olduğunu ve sınıfın bu anlamda homojen bir dağılıma sahip olduğunu göstermektedir.

- Öğrencilerin özellikle İngilizce yazma etkinliklerini gerçekleştirmede güçlük yaşadıkları dikkat çekmektedir.

- Ayrıca eğitim öğretim yılının birinci döneminde yazma becerisinin yer aldığı uygulama sınavında oldukça düşük puanlar almışlardır. Öğrencilerin yazma becerisi uygulama sinavinda 25 tam puan üzerinden 03-11 puan aralığında puanlar aldıkları gözlemlenmiştir.

\section{Veri Toplama Araçları}

Araştırmada, nitel veri toplama araçları kullanılmıştır. Merriam’a (2009) göre, nitel araştırmalarda araştırmacı veri toplama ya da veri analizi için belirli bir metot kullanmak zorunda değildir. Gözlemden görüşmeye çeşitli veri toplama araçlarından biri ya da birkaçı kullanılabilir. Nitel araştırmalarda araştırmacı, veri toplamak için çalışma yaptığı grubun doğal ortamında fazlasıyla zaman geçirir (Ocak ve Olur, 2019). Nitel araştırma yöntemlerinden biri olan eylem araştırmaları sistematik araştırmalardır. Bu nedenle veri toplama araçları, yöntemi ve süresi araştırmacıya bir özgürlük tanısa da sistematik bir yaklaşım belirlenmelidir. Çünkü eylem araştırması yöntemsel ve planlı bir gözlemdir (Schoen ve Nolen, 2004). Bu sebeple araştırmanın veri toplama süreci iki aşamada gerçekleştirilmiştir. Araştırmaya ilişkin ilk veriler eylem planlarının uygulanması sürecinde toplanmıştır. $\mathrm{Bu}$ süreçte veri toplama aracı olarak gözlem formu ve araştırmacı günlükleri kullanılmıştır. Araştırmaya ilişkin ikinci veri toplama basamağı ise görüşmelerin gerçekleştirilmesidir. Bu aşamada ise veriler yarı yapılandırılmış görüşme formları ile toplanmıştır.

Görüşme formun oluşturulmasında öncelikle ilgili alan taranmış ve araştırmaya temel oluşturacak kavramlar ve bu kavramların yer alacağı temalar belirlenmiştir. Daha sonra ilgili temalara derinlemesine veri sağlayacak alt temalar belirlenmiş, bu alt temalara ilişkin açık uçlu ve çok miktarda soru oluşturulmuştur. Formda yer alan tema ve alt temaların sorular ile ilişkisini incelemek başka bir ifade ile kapsam geçerliğini ve yapı geçerliğini sağlamak için Afyon Kocatepe Üniversitesi'nden bir alan uzmanı ve bir doktora öğrencisi tarafından gerekli incelemeler yapılmıştır. 


\section{Verilerin Analizi}

Araştırmada elde edilen veriler öncelikle görüşme öncesinde belirlenen tema ve alt temalara uygun olarak kodlanarak betimsel analiz yapılmıştır. Bununla birlikte verilerin incelenmesi sırasında ortaya çıkan yeni temalara uygun kodlamaların yapılması suretiyle de içerik analizi yapılmıştır. Dolayısıyla, araştırmada hem betimsel hem de içerik analizi kullanılmıştır.

\section{Geçerlik ve Güvenirlik}

Nitel araştırma yöntemleri, insan yaşamının ve sosyal dünyanın anlam ve deneyim boyutlarını anlamaya yönelik bir araştırma türüdür. Sandelowski ve Baaroso (2002), nitel araştırma yöntemlerinin epistemolojik yelpazesinin tek bir ölçüt setiyle temsil edilemeyecek kadar geniş olduğunu belirterek, evrensel olarak kabul görecek ölçütler geliştirme fikrine karşı çıkmaktadırlar. Bu durumda nitel araştırmalarda toplanan verilerin güvenilirliğini sağlamak için kullanılabilecek çeşitleme (triangulation), denetim izi (audit trail) ölçütleri, güvenduyulabilirlik (trustworthiness) gibi yöntemler vardır (Creswell ve Miller, 2000; Guba ve Lincoln, 1994; Patton, 1987). Bu yöntemler arasından çeşitleme iki ya da daha fazla veri toplama yönteminin, iki ya da daha fazla veri kaynağının sonuçlarının karşılaştırılmasıdır. Böylece yöntemlerden birinin zayıf yönleri diğer yöntemin güçlü yönleriyle telafi edilebilir (Mays ve Pope, 2000). Uzun süreli irtibat kurma ve sürekli gözlem sosyal kurmacılık-yorumculuk etkisiyle ortaya çıkan nitelik arttırıcı tekniklere örnek gösterilebilir (Creswell ve Miller, 2000). Bu gerekçelerle bu çalışmada araştırma soruları, veri toplama ve analiz teknikleri arasında uyum sağlanarak, uygun veri toplama ve analiz yöntemleri kullanılarak, çeşitli veri toplama araçları uyum içerisinde kullanılarak geçerlik ve güvenirlik sağlanmıştır.

\section{Uygulama}

Araştırma kapsamında öğrencilerle yazma becerisi dil öğrenme stratejilerinin ve yazma etkinliklerinin yer aldığı toplam üç farklı etkinlik üç ayrı eylem döngüsü ile gerçekleştirilmiştir. Eylem planlarının gerçekleşmesinde takip edilen aşamalar Şekil 1'de aşağıda yer almaktadır:

Şekil 1'de eylem planlarının (1., 2, ve 3. Eylem planları) uygulanması sürecinde takip edilen süreçler yer almaktadır. Eylem döngüsünün ilk aşaması olan eylem planında öğrencilere yazma becerisi dil öğrenme stratejilerinin neler olabileceğinin gösterildiği etkinliklere yer verilmiş ve öğrencilerin çıkarımda bulunmaları beklenmiştir. Bir sonraki aşama olan eylem uygulamasında ise öğrencilere sunulan etkinlikler yoluyla yazma becerisi dil öğrenme stratejilerinin neler olduğu gösterilmiştir. Öğrencilerin öğrendikleri yazma becerisi dil öğrenme stratejilerini uygulayabilmeleri için eylem planının derinleştirme bölümünde farklı yazma etkinlikleri ile karşılaşmaları sağlanmıştır. İzleme aşamasında öğrencilerin eylem planlarının uygulanması esnasında yazma becerisi dil öğrenme stratejilerine ilişkin etkinlilerdeki tutum ve davranışlarının gözlemlenmesi hedeflenmiştir. Yine uygulama esnasında öğrencilerin eylem planlarındaki durumlarını ele alan araştırmacı-uygulayıcı günlüklerine yer verilmiştir. Eylem döngüsünün son aşaması olan yansıtma basamağında öğrencilerle yazma becerisi dil öğrenme stratejilerine ilişkin gerçekleştirilen eylem planı hakkındaki görüşlerini ortaya çıkarmayı 
hedefleyen görüşmeler yapılmış ve eylem planlarına devam edilip edilmeyeceğinin kararı verilmiştir. Bu bağlamda araştırmada 3 eylem planı gerçekleştirilmiştir. Birinci eylem planının uygulanmasına ilişkin aşamalar Şekil 2' de yer almaktadır:

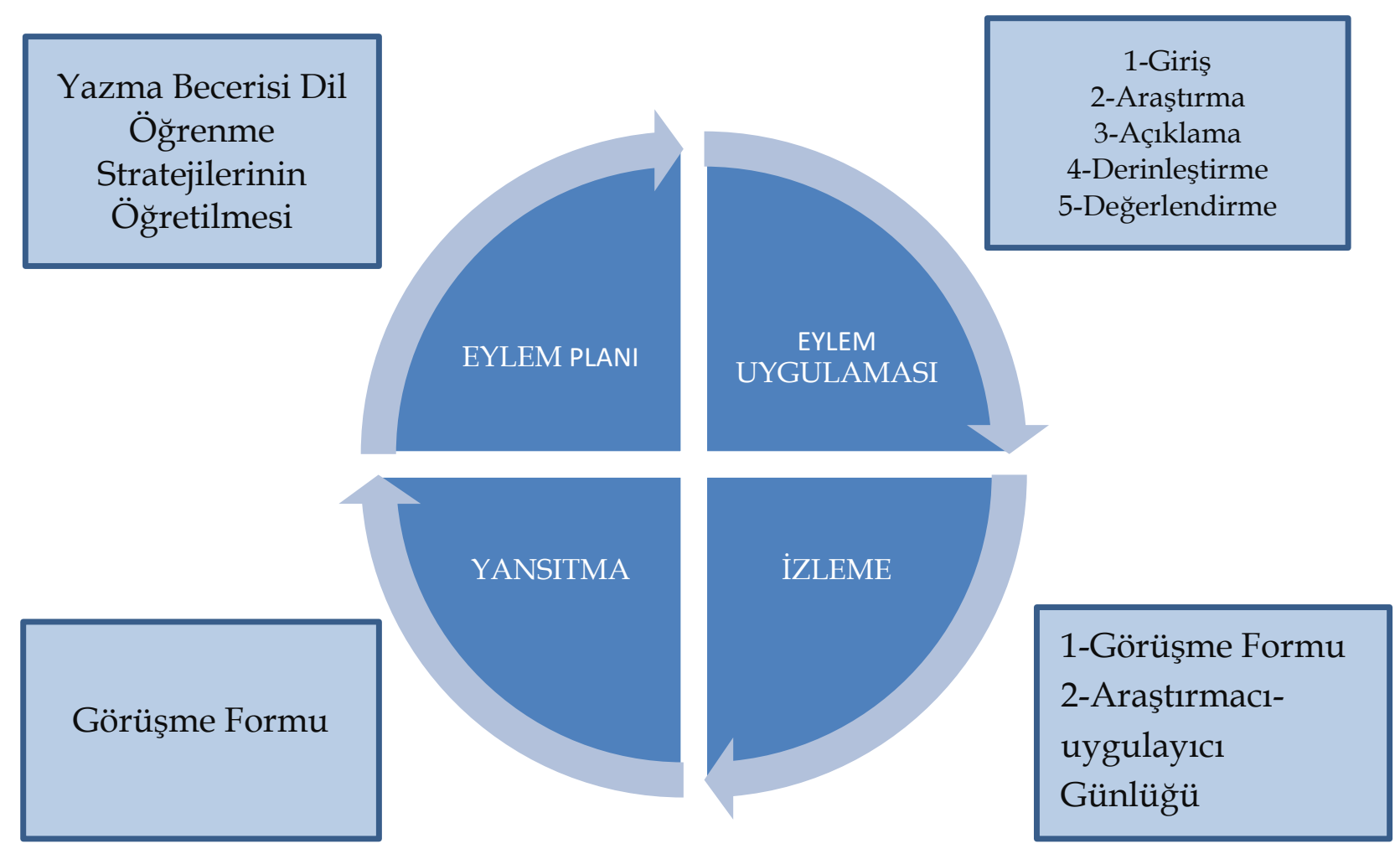

Şekil 1. Yazma becerisi dil öğrenme stratejilerinin öğretilmesine ilişkin eylem döngüsü

Şekil 2'de yazma öncesi dil öğrenme stratejileri kullanarak yazma etkinliklerini başarıyla tamamlamak amacıyla uygulanan eylem planı yer almaktadır. Eylem planın birinci basamağında öğrencilerin yazma öncesinde kullanabilecekleri bir takım stratejilerin var olduğunu göstermek için bir ısınma çalışması yapıldı. Isınma çalışmasında öğrencilerden öncelikle bir konu belirlemeleri istendi daha sonra da ellerine alfabenin harflerinin yer aldığ bir liste verildi ve konu ile ilgili bir liste yapmaları istendi. Öğrenciler yaptıkları bu liste ile hem konu ile ilgili geçmiş bilgilerini hatırlama imkânına sahip oldu hem de yazma becerisi öncesinde kullanabilecekleri bir stratejinin varlığından haberdar oldular. Bir sonraki aşamada ise öğrenciler bu kez belirlemiş oldukları konu ile ilgili olarak çok sayıda fikri yazdıkları bir beyin fırtınası etkinliği yaptılar. Daha sonra öğrenciler bu fikirlerden birbiri ile ilişkili olanları gruplandırdılar. Öğrencilerle, yazma becerileri ile ilgili dil öğrenme stratejilerinin daha fazla yer aldığı bir sunu paylaşıldı. Öğrenciler bu sunu ile hem yazma becerisi dil öğrenme stratejilerinin ne olduğu ve nasıl kullanılacağı ile ilgili fikir sahibi oldu hem de konuya ilişkin daha fazla strateji gördüler. Derinleştirme aşamasında ise öğrencilerden giriş bölümünde belirledikleri ve hakkında kelime ve fikir listesi yaptıkları konuya ilişkin taslak hazırlamaları istendi. Öğrenciler yazma metnine ilişkin taslağın nasıl hazırlanabileceğini açıklama bölümünde deneyimlediler. Daha sonra öğrenciler hazırlamış oldukları taslaktan ve 
kelime listesinden faydalanarak görüşlerini yazıya döktüler. Değerlendirme basamağında ise yazdıkları metni hazırlamış oldukları taslak ile karşılaştırıp doğru bir sıralama ile tamamlayıp tamamlamadıklarını sıra arkadaşları ile kontrol ettiler. Daha sonra öğrencilerin hazırlamış oldukları yazma metinlerini öğretmen kontrol etti. Öğretmen yazma metinlerinin kontrolü sırasında öğrencilerin bir kısmının stratejileri kullandığını, bir kısmının kelimeleri iyi hatırladığını ancak bir kısmının kelime eksiği yüzünden yazamadığını fark etmiştir. Ayrıca bazı öğrenciler kelime listesini hazırlamış, fikirleri listelemiş ancak taslak oluşturma aşamasından sonra herhangi bir ilerleme kaydedememişlerdir. Bu sebeple 2. Eylem planı tasarlanmıştır:

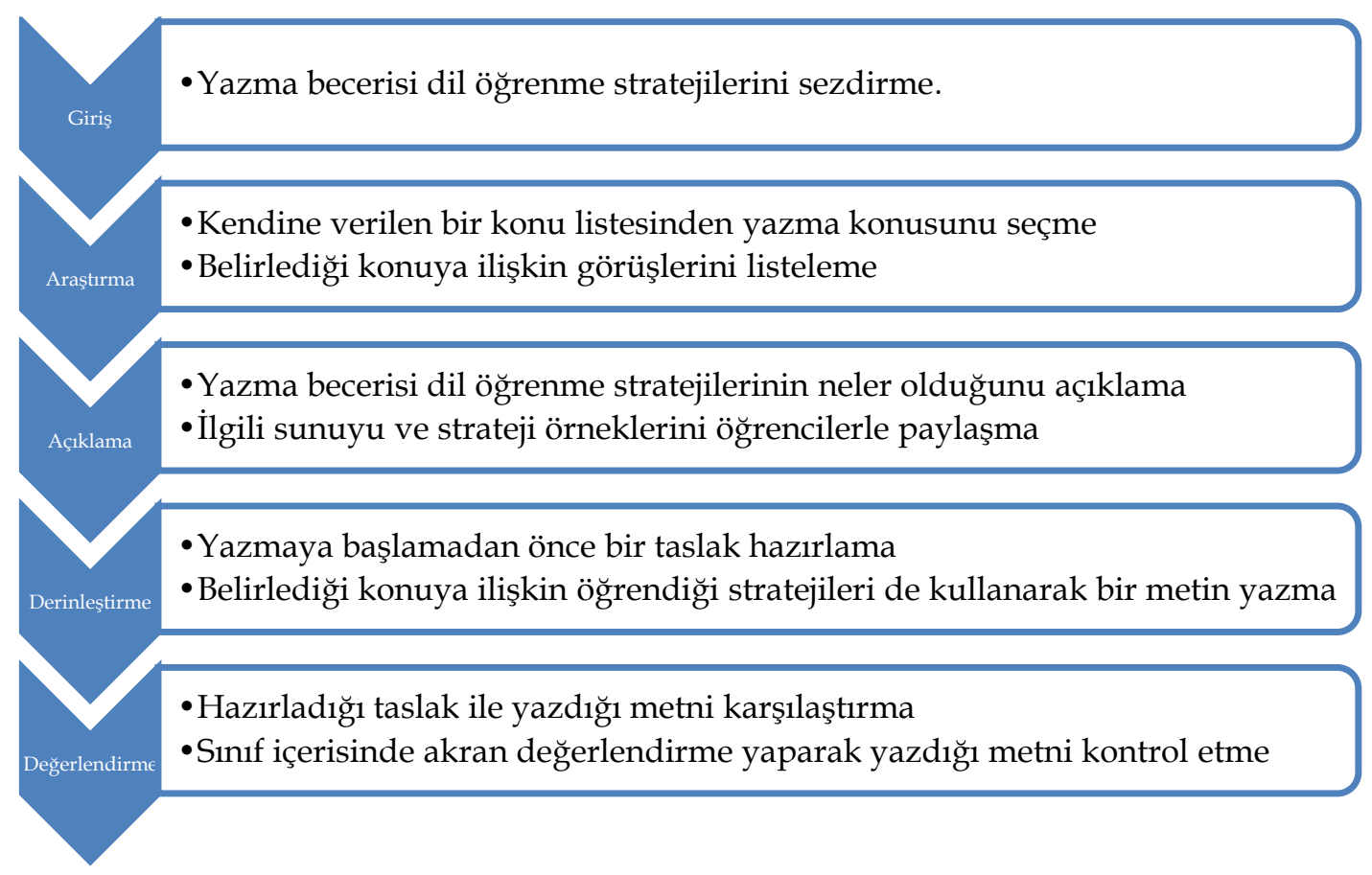

Şekil 2. 1. Eylem planının uygulanması 


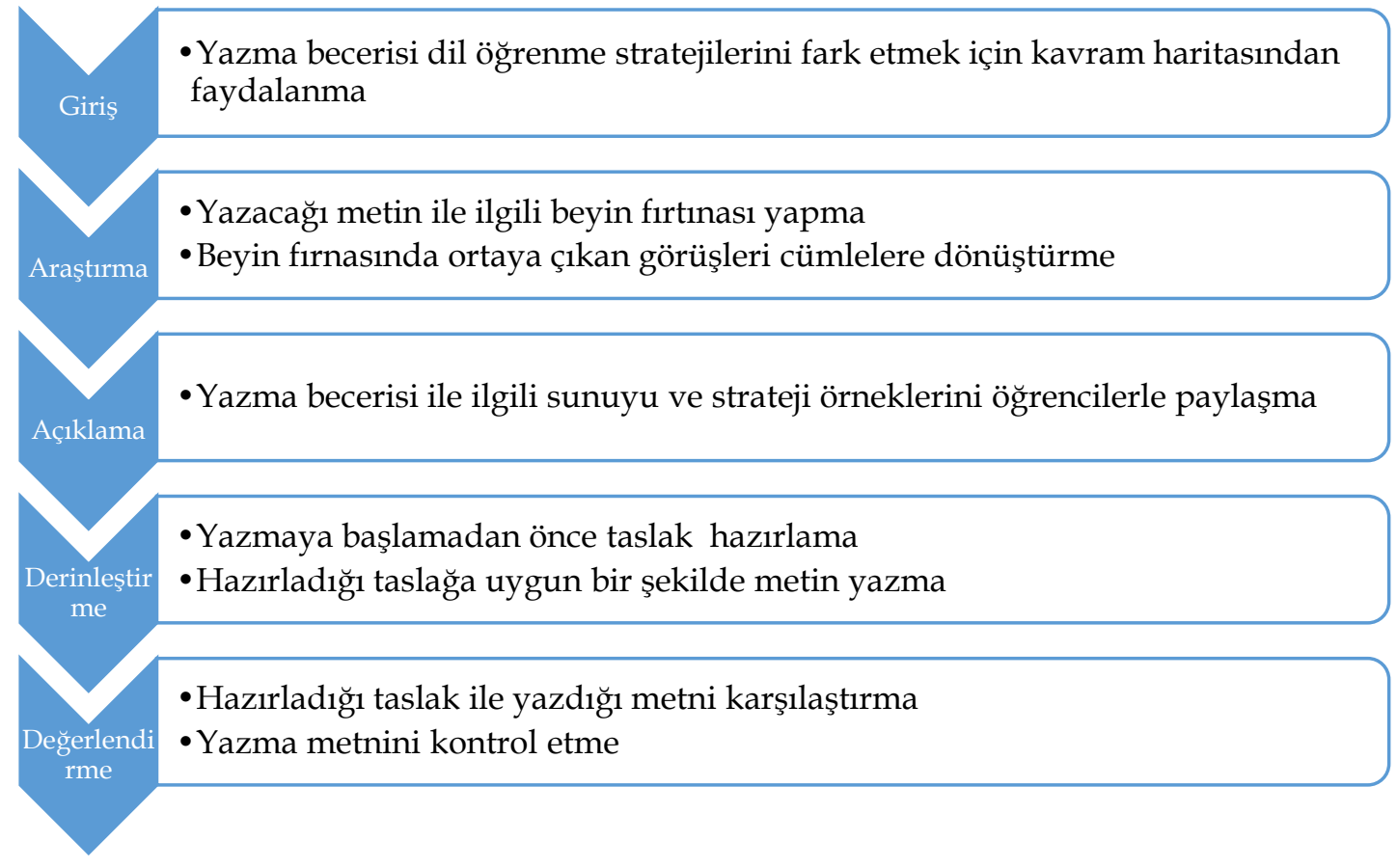

Şekil 3. 2. Eylem planının uygulanması

Şekil 3'te yazma öncesi dil öğrenme stratejileri kullanarak yazma etkinliklerini tamamlamak amacıyla uygulanan eylem planı yer almaktadır. Bu eylem planının ilk basamağında birinci eylem planından farklı olarak daha kontrollü bir çalışma gerçekleştirildi. Öncelikle tahtaya önceden belirlenmiş bir konu yazıldı. Daha sonra bu konuya ilişkin önceden doldurulmuş bir kavram haritası tahtaya yansıtıldı ve kavram haritasının ne olduğu ve nasıl kullanıldığına ilişkin bilgi verildi. Daha sonra öğrencilerden kendilerine verilen konu listesinden bir konu seçmeleri istendi. Öğrencilere boş bir kavram haritasının yer aldığı çalışma kâğıtları verildi ve bunu tamamlamaları istendi. Bir sonraki aşamada, öğrenciler kavram haritasına ek olarak yazacakları metin ile ilgili olarak beyin fırtınası yaptılar ve çok sayıda fikri sıraladılar. Öğrenciler kavram haritasında ve beyin fırtınasında şekillendirdikleri görüşlerini ve ifadelerini bu aşamada cümlelere dönüştürmeye çalıştılar. Daha sonra öğrencilerle yazma becerisi ile ilgili kullanabilecekleri çeşitli yazma becerisi dil öğrenme stratejilerinden örnekler paylaşıldı. Dersin derinleştirme aşamasında öğrenciler giriş ve araştırma aşamasında yaptıkları hazırlıkları açıklama aşamasında öğrendikleri ile birleştirerek taslak oluşturdular. Taslaklar hazırlandıktan sonra öğrenciler metinlerini yazmayı tamamladı. Değerlendirme aşamasında öğrencilerin hazırladıkları taslaklar ve yazma metinleri karşılaştıııldı. Sınıfta pek çok öğrencinin yazma metnini adım adım nasıl tamamlayacakları ile ilgili fikir sahibi olduğu görüldü. Öğrencilerin neredeyse tamamının kavram haritasını tamamladığı, fikirlerini listelediği, onları cümlelere dönüştürdüğü, taslak şablonu tamamladığı ve daha sonra yazma eylemine geçtiği görüldü. Öğrencilerin gerçekleştirdikleri bu aşamaları daha sistematik hale getirerek alışkanlık haline dönüştürebilmelerini sağlamak adına üçüncü ve son eylem planının tasarlanmasına karar verildi: 


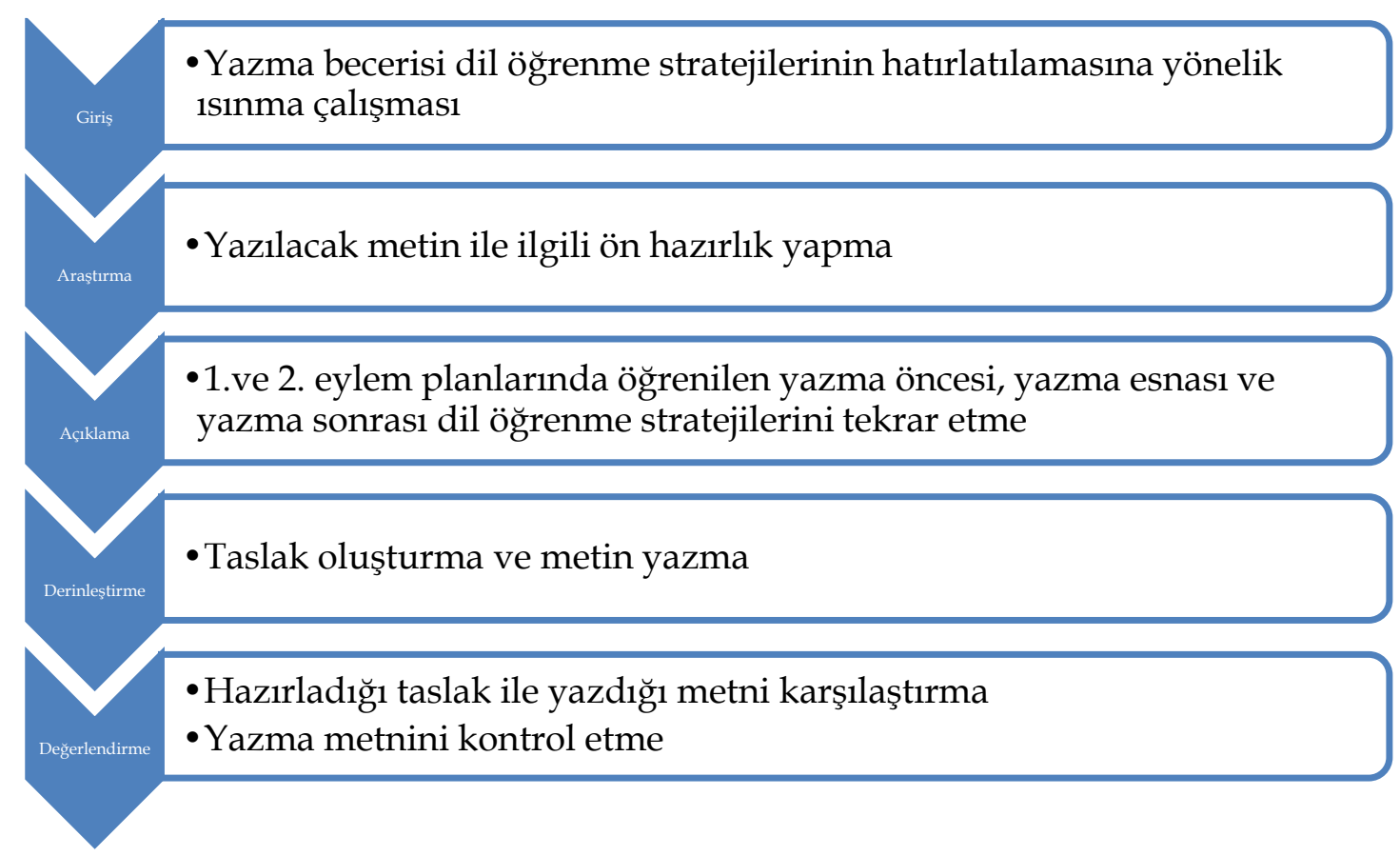

Şekil 4. 3. Eylem planının uygulanması

Şekil 4'te yazma öncesi dil öğrenme stratejileri kullanılarak yazma etkinliklerini tamamlamak amaciyla uygulanan eylem planı yer almaktadır. Eylem planının ilk aşamasında daha önceki iki eylem planında öğrencilerin karşılaşmış oldukları tüm yazma stratejileri beyin fırtınası yöntemi ile hatırlatıldı. Öğrencilerden bunları çeşitlendirmeleri ve kendilerine uygun yeni stratejiler türetmeleri istendi. Daha sonra öğrencilere farklı yazma konularının olduğu bir liste verildi. Öğrenciler bu listeden bir konu belirledi. Öğrenciler, konuyu belirledikten sonra öğrendikleri stratejilerden kendilerine uygun olanları seçerek yazma esnasında ve yazma sonrasında hangi stratejileri kullanacaklarını belirlediler. Daha sonra öğrencilere 1. ve 2. eylem planlarında görmüş oldukları tüm stratejiler tekrar edildi ve hangi durumlar üzerinde nasıl uyarlayabilecekleri konuşuldu. Daha sonraki aşamada öğrenciler taslak şablonlarını doldurdular ve metni yazdılar. Son aşamada ise taslak ile metin karşılaştırıldı ve yazma metni kontrol edildi. Sınıftaki bütün öğrencilerin taslak şablon oluşturdukları, yazma öncesinde hazırlık yaptıkları, yazma öncesi, esnası ve sonrası stratejileri kullanarak yazma metnini başarı ile tamamladıkları görülmüş bu sebeple eylem planları sonlandırılmıştır.

\section{Bulgular}

Yazma becerisi dil öğrenme stratejilerinin hazırlanan eylem planları ile gösterilmeye çalışıldığı bu çalışmada ortaöğretim 9. sınıf öğrencilerinin İngilizce yazma becerisinde karşılaştıkları problemlerin yazma becerisi dil öğrenme stratejileri ile ortadan kaldırılması ve onların yazma becerilerinin geliştirilmesi hedeflenmiştir. Araştırmada veriler iki aşamada toplanmışır bu sebeple araştırma bulguları da iki aşamada sunulmuştur. Verilerin sunulmasında, birinci aşamada eylem planı uygulama sürecindeki gözlem notları ile araştırmacı-uygulayıcının günlüğünden örnek ifadelere yer verilmiştir. İkinci aşamada ise uygulama sonrasında öğrencilerle 
yapılan görüşmelerin frekans tablosuna ve görüşmelerden örnek ifadelere yer verilmiştir.

Araştırmanın birinci alt problemi “İngilizce yazma etkinliklerinde yazma becerisi dil öğrenme stratejilerini kullanmanın yazma becerisine olumlu katkıları nelerdir?" sorusuna ilişkin gözlem, günlük ve görüşmelerden elde edilen örnek ifadelere aşağıda yer verilmiştir:

Gözlem:

"Yazma becerisi dil öğrenme stratejileri ile ilgili eylem planlarmın gerçekleştirildiği ilk derste öğrencilere doğrudan dil öğrenme stratejileri ile ilgili bilgi verilmedi. Öncelikle öğrencilerden yazmak istedikleri bir konu belirlemeleri istendi. Burada öğrenciler yazacaklarn konu ile ilgili olarak önceki bilgilerini de hatırlayabilecekleri bir kelime etkinliği yaptılar. Bu büyük oranda öğrencilerin yazacakları konu ile ilgili fikir sahibi olmalarına olanak sağladı. Bunun yanı sıra ögrenciler yazacakları konu ile ilgili olarak beyin firtınası yaptılar. Öğrencilere henüz yazma becerisi dil öğrenme stratejilerine ilişkin bir açıklama yapılmamış olmasına ră̆men, bu stratejiler dersin giriş ve araştırma bölümlerinde ipuçlar verilerek sezdirilmiştir. Daha sonra öğrencilere yazma becerisi stratejilerinin neler olduğu ve ne işe yaradığı açıklanmıştır. Böylece öğrenciler dersin ilk bölümlerinde hissettikleri bir takım stratejilerin ne işe yaradığını ve nasıl kullanacaklarını öğrenmişlerdir. Daha sonra öğrenciler nasıl taslak oluşturacaklarını öğrenmişler ve yazmaya başlamışlardır. Dersin en son aşamasında ise öğrenciler hazırladıkları taslak ile yazdıkları metinleri karşılaştırmışlardır. Öğrenciler bu ders öncesinde kendilerine verilen bir konuya ilişkin 1-10 arası cümle yazabilirken, stratejiler sonrasında 15-25 arasında cümle yazabilmişlerdir. Akran değerlendirme sonrasında ise öğrencilerin yazım ve dil bilgisi hatalarının azaldığı görülmüsstür." (12.11.2018)

\section{Araştırmac1-uygulayıcı Günlüğü:}

Yapılan ısınma çalışmasında kelime listesi kullanılması yazma öncesi dil öğrenme stratejilerinin öğretilmesinde oldukça etkiliydi. Öğrencilere yazma konusunu belirlemek için verilen liste seviyelerine uyumluydu. Yani öğrencilerin hem Ingilizce dersinde hem de strateji eğitiminin gerçekleştiği derslerde aynı konular üzerinde çalışıyor olması iki ders arasındaki ilişkiyi daha da güçlü hale getirdi. Öğrencilere yazma öncesinde paragraflarda nelerden bahsedileceğini belirten ipuçlar da çok işe yaradı. Yazma öncesi stratejileri uygulamalı olarak öğrenmelerini sağlayacak konu listesindeki konuların tamamı öğrencilerin aşina olduğu konulardı ve sayıca fazlaydı. Öğrenciler kendi konular ile ilgili yürüttükleri tahminleri öğretmenin onlara hazır olarak vermiş olduğu şablona yazdılar. Bu durum onlarn düşüncelerini organize etmelerini oldukça kolaylaştırdı. Bu etkinlikler esnasında sözlük de kullanıld yani başka bir ifade ile sözlük çalışması da yapıldı." (12.11.2018)

Eylem planı uygulama esnasında ele alınan gözlem notlarından ve araştırmacı-uygulayıcı günlüklerinden elde edilen veriler öğrencilerin bu stratejiler ile ilk kez karşılaştıklarını göstermektedir. Ancak öğrenciler ilk kez karşılaşmalarına rağmen etkinliklere oldukça istekli bir şekilde katılmışlardır. Öğrenciler belirli 
aşamaları takip ederek yazma metninin tamamlanabileceğini fark etmişlerdir. Yazma stratejileri ile ilgili sunum yapıldıktan sonra öğrencilerin bir kısmının stratejileri aktif bir şekilde kullanmaya başladıkları görülmüştür. Eylem planının uygulanmasından sonra yapılan görüşmelerden elde edilen verilerin frekans tablosuna (Tablo 1) ise aşağıda yer verilmiştir:

Tablo 1.

Görüşme Frekans Tablosu ve Görüşmelerden Elde Edilen Örnek İfadeler

\begin{tabular}{|c|c|c|}
\hline \multirow{6}{*}{$\begin{array}{l}\text { Tema } \\
\text { Yazma } \quad \text { Becerisi Dil } \\
\text { Öğrenme Stratejilerinin } \\
\text { Olumlu Tarafları }\end{array}$} & Alt Tema & $\mathrm{f}$ \\
\hline & Yazma öncesi hazırlık yapma & 32 \\
\hline & $\begin{array}{l}\text { Yazma öncesinde konuya ilişkin } \\
\text { daha önceden bildiği kelimeleri } \\
\text { hatırlama }\end{array}$ & 31 \\
\hline & $\begin{array}{l}\text { Yazma metni ile ilgili görüşlerini } \\
\text { sıralama, beyin fırtınası yapma }\end{array}$ & 31 \\
\hline & Yazma öncesi taslak hazırlama & 30 \\
\hline & $\begin{array}{l}\text { Hazırlanan taslak ile yazma } \\
\text { metnini karşılaştırma }\end{array}$ & 33 \\
\hline
\end{tabular}

Öğrenci Görüşleri:

"Yazma becerisi dil öğrenme stratejileri kompozisyon yazmaya başlamadan önce daha düzenli ve kolay cümleler kurmamızı să̆lıyor. İşimizi kolaylaştırıyor. Ingilizce yazı yazmak aslında çok basit. Biraz bilgisi olan birisi kolayca yazabilir; ben yazamıyorum diyen birisi bu yazma becerisi stratejilerini kullanarak düzenli ve kolayca yazabilir. Daha kolay cümle kurabilmenin en iyi yolu bence bu stratejiler. Yazma becerisi dil öğrenme stratejilerinin çok önemli olduğunu düşünüyorum. Yazma esnasında hız kazanmama yardımcı oldu. Ben ilk başta hiç yazamazdım ve bu yüzden dersi sevmezdim. Şimdi ise bu yaptığımız stratejiler sayesinde daha kolay anlıyor ve dersi seviyorum. Bu hafta yaptığımız etkinliklerin başarımı çok etkilediğini düşünüyorum. Bu hafta yaptı̆̆ım etkinliklerde kendimi özellikle fikir üretmekte ve bu fikirleri bana verilen tablo ve haritalara yerleştirmekte güçlü hissettim. Ancak fikirlerin İngilizcesini yazmada güçlü değildim sürekli sözlüğe baktım ve öğretmenimize sordum. Ama ĕger çok film izlersem ve kitap okumaya çalışırsam kelime hazinemin çok daha iyi olacağını biliyorum". (Ö3-12.11.2018)

1.Eylem planının uygulanmasından sonra öğrencilerle eylem planı hakkındaki değerlendirmelerini almak için görüşmeler yapılmıştır. Öğrencilerin yazma becerisi dil öğrenme stratejilerini uygulanabilir buldukları görülmektedir. Yazma becerisi dil öğrenme stratejileri öğrencilerde heyecan yaratmıştır. Öğrenciler ilk eylem planında bile kendilerine verilen bir yazma görevini yerine getirebildiklerini ve stratejilerin dil öğrenme sürecini kolaylaştıracağını fark etmişlerdir. Öğrenciler dersin araştırma, açıklama aşamalarından sonra yer alan derinleştirme aşamasında öğrendiklerini uygulamışlardır. Bu durum öğrencilerin yazma becerisine ilişkin olan tutumlarının olumlu anlamda değişmesine olanak tanımıştır. Öğrenciler bir takım stratejiler kullanarak yazma etkinliklerinde başarılı olabileceklerini göstermiştir.

Araştırmanın ikinci alt problemi olan 'İngilizce yazma etkinliklerinde yazma becerisi dil öğrenme stratejilerini kullanmanın olumsuz yönleri nelerdir?’ sorusuna 
ilişkin gözlem, günlük ve görüşmelerden elde edilen örnek ifadelere aşağıda yer verilmiştir:

Gözlem:

"Yazma becerisi dil öğrenme stratejilerinin ele alındiğı derslerde öğrencilerin yazma becerisi ile ilgili tüm stratejileri diğer becerilerdeki stratejilere göre çok daha çabuk benimsediklerini ve stratejilerin çoğunu aktif bir şekilde kullandıkların gözlemledim. Evet, konuşma ya da okuma gibi diğer becerilerde de kullanyyorlardı ancak özellikle yazma becerisinde bu stratejileri daha somut bir şekilde görebildim. Kendilerine çalışma kâğıdı verilip yönergeler söylendiğinde ögrencilerin hemen farklı bir kâğıda bir taslak hazırladıklarını, konuyu yazmaya başlamadan farklı bir yerde kendi kendilerine beyin firtınası yaptıkların, konu ile ilgili bildikleri kelimeleri ve düşüncelerini ayrı ayrı yazdıkların gördüm. Yazma işlemini tamamladıktan sonra çalışmaların doğrudan öğretmene teslim etmediler. Öğretmen yeni bir yönerge vermedi ama öğrenciler sıra arkadaşlarıly değişip birbirlerinin çalışmalarını kontrol ettiler. Bana en çok heyecan veren şey kontrol ederken ögrrencilerin taslaklarn ve metni yan yana koyup karşılaştırma yaparak kontrol etmeleriydi. Bu hafta ders kazanımlar, içerik, etkinlikler, ölçme değerlendirme araçlarında yer alan sorular birbiriyle uyumluydu. Uygulama esnasinda siniflarda her hangi bir problem olmadı." (19.11.2018)

Araştırmac1- uygulayıcı Günlüğü:

"Öğrencilerin bu stratejileri edinebilmesi için yazma öncesinde ve yazma esnasinda kullanilabilecek stratejileri aktif bir şekilde kullanabiliyor olmalar gerekiyordu. Öğrencilerin yazma becerisine ait diğer stratejileri aktif bir şekilde kullanmaları yazma sonrası dil öğrenme stratejilerinin kolay öğrenilmesini sağladı. Öğrenciler yazma konusunu duyduklarında ilk olarak "şablon yapalım mı?" diye sordular. Bu durum öğrencilerin diğer yazma stratejilerini aktif bir şekilde kullandıkların gösteriyordu. Bu durum yazma sonrası stratejilerinin öğretimi için güçlü bir yön oluşturdu." (19.11.2018)

2. Eylem planının uygulanması esnasında toplanan veriler, öğrencilerin yazma becerisi dil öğrenme stratejilerini aktif bir şekilde kullanmaya başladiklarını göstermiştir. Aynı zamanda öğrencilerin yazma metnine başlamadan önce taslak hazırlaması yazma metninin niteliğini olumlu anlamda etkilemiştir. Öğrencilerin hem yazdikları cümlelerin sayısı artmış hem de daha doğru cümleler yazmaya başlamışlardır. 2. Eylem planının uygulanmasından sonra yapılan görüşmelerden elde edilen verilerin frekans tablosuna (Tablo 2) ise aşağıda yer verilmiştir.

Tablo 2.

Görüşme Frekans Tablosu ve Görüşmelerden Elde Edilen Örnek Iffadeler

\begin{tabular}{|c|c|c|}
\hline Tema & Alt Tema & $\mathrm{f}$ \\
\hline Becerisi & Vakit kaybına neden olma & 1 \\
\hline Öğrenme Stratejilerinin & Kelime hatırlamakta zorlanma & 2 \\
\hline Olumsuz Tarafları & Ön bilgileri hatırlamakta zorlanma & 3 \\
\hline & Taslak hazırlamakta zorlanma & 2 \\
\hline & Akran değerlendirmeye ihtiyaç duymama & 2 \\
\hline
\end{tabular}


Öğrenci Görüşleri:

"Bu hafta İngilizce yazmak ne demek onu öğrendik aslında. Öğretmenimiz yazma öncesinde neler yapacaklarımızı anlattl. Yazma öncesinde önce yazacă̆ımı konuyu belirlemeliyiz. Konuyla ilgili anahtar kelimeleri yazmamız gerektiğini öğreten çalışma kâ̆ğılı çok yararlıydı. Ama benim kelime bilgim zaten zayıftı o yüzden çok fazla kelime hatılayamadım. Ayrıca kavram haritası hazırlamak zordu. İkinci kâğıtta yazmaya nasıl başlanacağını öğrendim. Burada tam anlatamadım ama etkinliği çok iyi yaptım. Sinıfimızda gözlemci olan öğretmenimize gösterdim, o da çok beğendi." (Ö2-19.11.2018)

2. Eylem planı uygulama sonrasında yapılan görüşmelerde öğrencilere yazma becerisi dil öğrenme stratejileri ile ilgili olarak olumsuz gördükleri şeylerin neler olduğu sorulmuştur (Tablo 2). Öğrencilerden çok azı yazma becerisi dil öğrenme stratejilerinin olumsuz yanlarının olduğunu ifade etmişlerdir. Öğrencilerden birkaçı bu stratejilerin vakit kaybına neden olduğunu söylemiştir. Yine birkaç öğrenci metinle ilgili kelimeleri hatırlamakta zorlandıklarını belirtmişlerdir. Bazı öğrenciler de taslak hazırlamakta zorlandıklarını ifade etmişlerdir.

Araştırmanın üçüncü alt problemi olan 'İngilizce yazma becerisi dil öğrenme stratejilerinin öğrencilerin yazma becerilerinin gelişimine katkısı nasıldır?' sorusuna ilişkin gözlem, günlük ve görüşmelerden elde edilen örnek ifadelere aşağıda yer verilmiştir:

Gözlem:

Öğrenciler bu hafta yapılan ısınma çalı̧̧ması ile çok ilgilendiler. Öncelikle bu haftanin konusu ile ilgili daha sonra da kendi yazacaklart ile ilgili beyin firtmast yapıldı. Öğrenciler eski bilgilerinden yola çıkarak, yazma esnasında kullanılabilecek dil öğrenme stratejilerinin neler olabileceğini tahmin ettiler. Öğrencilerin tahminleri oldukça başarılıydı. Öğrenciler kendi konularn ile ilgili yürüttükleri tahminleri, öğretmenin onlara hazır olarak vermiş olduğu şablona yazdılar. Öğrenciler her aşamada ne yapacaklarmı çok iyi öğrenmişlerdi. Neredeyse sinıfin tamamı oldukça detaylı taslak hazırlamıştı." (26.11.2018)

Araştırmacı-uygulayıcı Günlüğ̈̈:

"Isınma çalısmasinda verilen üçüncü konu biraz zordu. O konu biraz daha basit hale getirilebilir ya da öğrencilerin daha fazla kelime dağarcı̆̆ına sahip olduğu düşü̈ülen bir konu seçilebilirdi. Yine ısınma çalışmasındaki konular ile asıl etkinlikte verilen konular birbirinden farklı konulardı. Bazı öğrenciler ilk çalışıkları konu ile devam etmek istediler. Bu iki konu listesi (ısınma çalışmasındaki liste-asıl uygulamadaki liste) birleştirilebilir. Uygulama esnasında birleştirildi ancak teoride de birleşebilir. Yazma konu listesindeki konuların tamamı öğrencilerin aşina olduğu konulardı ve sayıca fazlaydı. Bu sebeple her ögrenciye hitap eden bir konu oldu." (26.11.2018)

Eylem planlarının uygulanması esnasında yapılan gözlem ve araştırmacı uygulayıc1 günlüğü öğrencilerin yazma becerisi dil öğrenme stratejilerini kullandıklarında yazma etkinliklerinde daha başarılı olduklarını ve motivasyonlarının daha yüksek olduğunu göstermektedir. Eylem planlarının 
uygulanmasından sonra ise öğrencilerle görüşmeler yapılmıştır. Görüşmelerden elde edilen verilere ilişkin frekanslar Tablo 3'te verilmiştir:

Tablo 3

Görüşme Frekans Tablosu ve Görüşmelerden Elde Edilen Örnek Iffadeler

\begin{tabular}{lrll}
\hline TEMA & & ALT TEMA & $\mathrm{f}$ \\
\hline Yazma & becerisi dil & Yazma becerisine karşı olumlu tutum geliştirme & 32 \\
öğrenme & stratejilerinin & Yazma öncesi ön bilgilerini hatırlama & 30 \\
dinleme & becerisine & Yazma öncesi taslaktan faydalanma & 32 \\
katkısı & & $\begin{array}{l}\text { Akran değerlendirme ile hatalarını fark etme ve } \\
\text { düzeltme }\end{array}$ & \\
\hline
\end{tabular}

Öğrenci Görüşleri:

Yazma becerisi için kullanılabilecek stratejiler artık benim için çok şey ifade ediyor. Üç haftadır yazma ile ilgili stratejiler görüyoruz. Kendimde üç haftadır yazma ile ilgili çok ilerleme görüyorum. Eskiden üç cümle bile yazamazken şimdi önce planlayıp sonra da yazarak giriş-gelişme-sonuç paragraflarmdan oluşan bir metin yazabiliyorum. Aslinda kendimi bu hafta genel olarak artık yeterli buldum. Bizim nasıl daha iyi yazabileceğimizi gösteriyor. Bunların hepsinin çok işime yarayacă̆ın biliyorum. Kendimi bu hafta kelime konusunda yetersiz hissettim. Aslında kelimeleri çok iyi biliyorum hem Türkçesini hem de İngilizcesini. Ama yazmaya başladığımda o kelimeyi bir türlü hatırlayamadım. Bu konuda yetersiz hissettim. Sinıfimıza gözlemci olarak gelen öğretmenimize sorduğumda o bana ne kadar sık kullanırsam o kadar çok çabuk aklıma geleceğini söyledi. Internet üzerinden sohbet ederek ya da kendime mektup arkadaşı bularak bu konuda kendimi geliştirebileceğimi söyledi." (Ö5-26.11.2018)

3. Eylem planının uygulanmasından sonra öğrencilerle yapılan görüşmelerde öğrencilere yazma öncesi dil öğrenme stratejilerinin yazma becerisinin gelişimine nasıl katkı sağladığı sorulmuştur. Öğrencilerin büyük çoğunluğu yazma becerisinde karşılaştıkları sorunların büyük oranda ortadan kalktığını ifade etmişlerdir. Öğrenciler yazma etkinliklerine karşı olan olumsuz duygularının kısmen azaldığını belirtmişlerdir. Yazma metni ile ilgili nasıl bir ön hazırlık yapacakları konusunda fikir sahibi olduklarını vurgulamışlardır.

\section{Tartışma, Sonuç ve Öneriler}

İngilizce yazma becerisi, dil öğrenme sürecinde dil öğrenmenin başlaması için oldukça önemlidir. Bu önem, yazma becerisinin hedef dilin hem dil bilgisi yapılarının hem de kelime bilgisinin kullanılmasından kaynaklanmaktadır. Bu çalışmada öğrencilere beceri tabanlı dil öğrenme stratejilerinden yazma becerisine ilişkin stratejilerin öğretilerek onların yazma becerilerinin geliştirilmesi amaçlanmıştır. Öğrenciler yazma becerisinin gelişebilmesi için zamana ve dil ile etkileşim içerisinde olmaya ihtiyaç duyarlar. Bu nedenle çalışma tek bir eylem planı ya da tek bir etkinlikle değil, üç eylem planı ve daha fazla etkinlikle gerçekleştirilmiştir.

Üç haftalık yazma stratejileri eylem planlarının yer aldığı öğretim sürecinden sonra öğrencilerin strateji öğretimi öncesi yazma metinleri ve öğretim sürecindeki 
yazma metinleri sırası ile karşılaştırılmıştır. Öğrencilerin strateji öğrenmeden önceki paragrafları oldukça kısadır ve cümleler arası geçişler uygun değildir. Stratejileri kullanmaya başladıkları haftadan itibaren ise öğrenciler paragraflardan oluşan yazma metinleri ortaya koymuşlardır. İlk hafta paragraflar oldukça kısa iken ikinci ve son haftada paragraflar kelime ve cümle sayısı açısından oldukça zengindir. Bu durum, strateji öğretiminin öğrencilerin daha yapılandırılmış ve anlamlı paragraflar yazma becerilerini geliştirmeye katkı sağladığını göstermektedir. Öğrenciler iyi yapılandırılmış bir paragrafın en önemli özelliklerinden olan paragrafın ilk cümlesini oldukça odaklanarak yazmışlar ve paragrafın içeriği ile ilgili ipucu veren ifadeler kullanmışlardır. Bununla birlikte öğrenciler açık ve anlaşılır paragraflar oluşturmadan önce nasıl taslak hazırlanacağını öğrenmişlerdir. Bu konuyla ilişkili olarak Indra' nın (2004) yaptığ çalışmada görsel şablonlar, taslak ya da görsel sunular hazırlayan öğrencilerin yazma becerilerinin hazırlamayan öğrencilere göre daha iyi olduğunu ortaya koymuştur. Bu doğrultuda yazma öncesi hazırlanan taslakların ya da şablonların hazırlanan metnin niteliğini olumlu olarak etkiledikleri söylenebilir.

Eylem planlarının ilk uygulama basamaklarında kelime çalışmalarının yanı sıra öğrenciler yazacakları konu ile ilgili beyin fırtınası yapmışlar ve belirledikleri konuya ilişkin görüşlerini sıralamışlardır. Öğrenciler bu işlemi ilk eylem planından sonraki derslerde otomatik olarak yapmaya başlamışlardır. Mu ve Carrington (2007) ile Riduan ve Lim (2009) bu konuya ilişkin olarak özellikle üst düzey İngilizce seviyesine sahip olan öğrencilerin yazma becerisine ilişkin stratejilerin daha çok farkında olduklarını vurgulamışlardır. Yine bu öğrencilerin kendi mevcut bilgilerini aktif hale getirmek için beyin fırtınası yöntemini kullandıklarını yazma konusu ile ilgili fikirlerini gruplandırdıklarını ifade etmiştir. Bu durum yazma öncesi beyin fırtınası etkinliklerinin yazma sürecini olumlu bir şekilde etkilediğini göstermektedir.

Araştırmada yazma metinlerinin ilk hali bittikten sonra akran değerlendirmesinin yapılması öğrencilerin hatalarını fark etmesine fırsat tanımıştır. Böylece öğrenciler birbirlerinden öğrenme fırsatını da yakalamışlardır. Ayrıca akran değerlendirme ile öğrenciler birbirlerini dinlemeyi, iş birliği içerisinde çalışmayı, hem aktif hem de otonom öğrenenler olmayı öğrenmişlerdir. Öğrenciler öğrendikleri ve kendilerine göre uyarladıkları bir takım stratejileri paylaşma şansına sahip olmuşlardır. Jahin'e (2012) göre, akran değerlendirme öğrencilere yazmak için bir amaç ve yazmış oldukları çalışmaya çeşitli bakış açıları kazanmalarına olanak sağlar. Ayrıca akran değerlendirmenin yazma ürününe ve yazma sürecine pozitif etkilerinin olduğunu vurgular. Hansen ve Liu (2005) akran değerlendirmenin öğrenenlerin yazma becerilerinin gelişmesine ve kendilerine olan güvenin artmasına yardımcı olduğunu ifade ederler. Buna ek olarak yazma sürecinde akran değerlendirmenin yazma becerisinde işbirlikli öğrenmeyi geliştirdiğini vurgular. Dolayısıyla, yazma sürecinde, akran değerlendirmenin etkin kullanılması, hem öğrenciler arasında iş birliğini artırmakta hem de metnin niteliğini etkilemektedir.

Dil öğrenme sürecinde beceri temelli dil öğrenme stratejilerini kullanarak dilin işlevselliğini artırmak son zamanlarda dil öğrenme sürecinde takip edilen yollardan birisidir. Bu çalışmada da öğrencilere bir takım yazma stratejileri öğretilerek yazma becerilerinin gelişimlerine katkı sağlanmıştır. Kieft, Rijlaarsdam ve van den Bergh (2006) yaptığ1 çalışmada planlama ve gözden geçirme stratejilerini öğreterek ve kullanmalarını sağlayarak öğrencilerin yazmayı öğrenmelerini sağlamıştır. Araştırma 
sonuçları yazma stratejilerinin dikkate alınarak yapıldığı dersler neredeyse tüm öğrencilerin yazma becerisine katkı sağlamıştır. Bu durum, bir program dahilinde öğrencilere dil öğrenme stratejilerine ilişkin öğretim yapıldığında öğrencilerin hedef becerileri daha kısa sürede ve hızlı edindiklerini göstermektedir.

Yine Watt-Taffe ve Truscott (2000) yaptıkları çalışmada önceki mevcut bilgilerini hatırlatarak öğrencilerin yazma becerilerine katkı sağlamayı amaçlamışlardır. Çalışmada İngilizce öğrenen öğrencilere kendilerine verilen yazma görevine ilişkin ne bildiklerini hatırlamaları istenmiş bunun için kendilerine sorular verilmiş, konuya ilişkin bu soruları cevaplamaları istenmiştir. Daha sonra öğrenciler bu bilgilerden hareketle yazacakları konuya odaklanmış ve yazma görevini başarıyla tamamlamışlardır. Benzer şekilde bu çalışmada da özellikle 1sınma çalışması bölümlerinde öğrencilere mevcut bilgileri hatırlatılmaya çalışılmıştır. Öğrencilerin mevcut bilgilerini hatırlamaları onların bir sonraki etkinliğe geçişlerini hızlandırmıştır. Bu durum yazma becerisinde önceki bilgileri hatırlatma stratejisinin bu becerinin gelişimine katkı sağladığını göstermektedir.

Maarof ve Murat (2013) yaptıkları çalışmada ana dilde yazma ile yabancı dilde yazma arasında fark olduğunu ifade etmişlerdir. Özellikle yabancı dilde yazmanın karmaşık bir süreç olduğunu ve çeşitli stratejiler kullanmayı gerektirdiğini ifade etmişlerdir. Öğrencilerin bir kısmı üst düzey İngilizce seviyesine sahipken bir kısmı da düşük düzeyde İngilizce seviyesine sahiptir. Araştırma sonuçları yazma esnasında kullanılabilecek olan stratejilerin çok daha sık, gözden geçirme stratejilerinin ise en az kullanıldığını göstermektedir. Öğrencilerin strateji kullanım sıklıkları birbirine benzemektedir. Ancak kullandıkları stratejilerin türü farklıdır. Araştırmada elde edilen sonuçlardan birisi de öğrencilerin yazma becerisi stratejilerini kullanmaları konusunda cesaretlendirilmeleridir. Bu çalışmada ise eylem planlarının uygulanması sürecinde, derslerin başlangıcında ve etkinliklerin gerçekleştirilmesi esnasında duyuşsal stratejilerden faydalanılmıştır. Başlangıçta yazma becerisine ön yargılı bir şekilde yaklaşan öğrencilerin yazma etkinliklerine katılma isteklerinin arttığ gözlemlenmiştir. Bu durum yazma becerisi stratejileri ile birlikte duyuşsal stratejileri kullanmanın önemini göstermektedir.

Öğrenciler yazma stratejilerinden sonra daha planlı, organize edilmiş ve aşama aşama yazmayı öğrenmişlerdir. Üç haftalık öğrenme sürecinden sonra öğrenciler yazma becerisinin beş temel unsuru olan içerik, organizasyon, kelime bilgisi, dil bilgisi ve işbirlikli yazma konusunda ilerleme kaydetmişlerdir. Yazma becerisine karşı olan ilgileri ve odaklanmaları artmıştır. Bu konuya ilişkin Calp (2013), öğretmenlerin yazma çalışmalarında uygulamaya ağırlık vermesi gerektiğini ve yazmanın yaparak yaşayarak öğrenileceğini söylemektedir. Bu bakımdan öğretmenlerin yazı çalışmalarına derslerinde yer vermeleri yazma becerisinin kazandırılmasında önemli bir rol oynamaktadır. Zamana yayılan ve devamlılık gösteren yazı çalışmalarının öğrencilerde yazma becerisinin gelişimine olumlu katkılar sağlayacağı da vurgulanmaktadır. Bu sebeple, planlı ve sürekli yazma becerisi stratejilerinin yazma etkinliklerinde kullanılması, öğrencilerin yazma becerilerini geliştirecektir.

Göçer (2010), öğrencilerin yazı çalışmalarına severek ve isteyerek katılması için onların yazma yöntem ve teknikleri bakımından donanımlı hale getirilmesi gerektiğini ifade etmektedir. Bu durum yazma becerisine ilişkin çalışmalarda 
öncelikle öğrencilere ön bilgilerini hatırlamalarını sağlayacak stratejilerin kazandırmanın önemini göstermektedir. Bununla birlikte bu çalışma yazma becerisine ilişkin stratejiler ile birlikte öğrencilerin bu beceriye ilişkin ön yargılarını ortadan kaldırmak ve bu beceriyi sevmelerini sağlamak amacıyla duyuşsal stratejilerin de işe koşulması gerektiğini göstermektedir. Yazma becerisine ilişkin stratejilerin öğretilmesi hem yazma becerisi ile birlikte hedef dilin gelişimine hem de hedef dilin işlevsel olmasına katkı sağlayacaktır. Yazmayı sevme, yazmaktan keyif alma ve yazma noktasında yeterli bilgiye sahip olma yazma becerisini geliştirecektir.

\section{Kaynakça}

Berry, R. (2007). Assessment for learning. Hong Kong University Press, Hong Kong. Büyüköztürk, Ş. (2012). Sosyal bilimler için veri analizi el kitabı. Pegem Akademi, Ankara.

Calp, M. (2013). Serbest ve yaratıcı yazma tekniğine göre oluşturulan kompozisyonların yazılı anlatımın niteliği ve puanlama tekniği açısından karşılaştırılması. Turkish Studies, 8(9), 879-898. https:// doi.org/10.7827/TurkishStudies.5340

Canagarajah, A. (2002). Multilingual writers and the academic community: towards a critical relationship. Journal of English for Academic Purposes, 1(1), 2944. https:/ / doi.org/10.1016/S1475-1585(02)00007-3.

Chamot, A.U. (2004). Issues in language learning strategy research and teaching. Electronic Journal of Foreign Language Teaching, 1(1), 14-26.

Cohen, A.D. (1990). Language learning. Heinle ve Heinle Publishers, Boston.

Creswell, J.W. and Miller, D.L. (2000). Determining validity in qualitative inquiry. Theory into Practice, 39(3), 124-131. https://doi.org/10.1207/s15430421tip3903_2

Duffy, G. (1982). Fighting off the alligators: what research in real classrooms has to say about reading instruction. Journal of Reading Behavior, 14, 357-374. https:// doi.org/10.1080/10862968209547464

Göçer, A. (2010). Türkçe öğretiminde yazma eğitimi. Uluslararası Sosyal Araştırmalar Dergisi, 3(12), 178-195.

Graham, S. ve Perin, D. (2007). Writing next: effective strategies to improve writing of adolescents in middle and high schools. Carnegie Corporation of New York, New York.

Guba, E.G. and Lincoln, Y.S. (1994). Competing paradigms in qualitative research. In N.K. Denzin ve Y.S. Lincoln (Eds.), Handbook of qualitative research (pp. 105117). Thousand Oaks, CA: Sage.

Hansen, J.G. and Liu, J. (2005). Guiding principles for effective peer response. ELT Journal, 59, 31-38. https:/ / doi.org/10.1093/elt/cci004

He, T.H. (2005). Effects of mastery and performance goals on the composition strategy use of adult EFL writers. Canadian Modern Language Review/La Revue canadienne des langues vivantes, 61(3), 407-431. http:/ / dx.doi.org/10.3138/cmlr.61.3.407

Indra, G. (2004). The use of mind mapping strategy to improve students 'ability in writing procedure text (an action research at the tenth grade of SMA Negeri 1 
Susukan Kabupaten Semarang) (doctoral dissertation, universities negeri semarang). Journal of second language writing, 8, 1-11.

Jahin, J. H. (2012). The effect of peer reviewing on writing apprehension and essay writing ability of prospective EFL teachers. Australian Journal of Teacher Education, 37(11), 60-84. https:// doi.org/10.14221/ajte.2012v37n11.3

Karim, A. A. (2012). Cooperative Learning Strategies in Enhancing Students' Writing Proficiency: The Case of Second Year LMD Students at Mohamed Khidher University (Master's thesis). University of Mohamed Khidher Biskra, Biskra.

Kieft, M., Rijlaarsdam, G. and Van den Bergh, H. (2006). Writing as a learning tool: Testing the role of students' writing strategies. European Journal of Psychology of Education, 12(1), 17-34. https:/ / doi.org/10.1007/BF03173567

Kustati, M. and Yuhardi, T. (2014). The effect of the peer-review technique on students' writing ability. Studies in English Language and Education, 1(2), 71-81. https:// doi.org/10.24815/ siele.v1i2.2671

Maarof, N. and Murat, M. (2013). Writing strategies used by ESL upper secondary school students. International Education Studies, 6, 47. https:// doi.org/10.5539/ies.v6n4p47

Mays, N. and Pope, C. (1995). Qualitative research: rigour and qualitative research. British Medical Journal, 311, 109-112. https:/ / doi.org/10.1136/bmj.311.6997.109

Merriam, S.B. (2009). Qualitative research: A guide to design and implementation. JosseyBass, San Francisco.

$\mathrm{Mu}, \mathrm{C}$. and Carrington, S. (2007). An investigation of three Chinese students' English writing strategies. TESL-EJ, 11(1), 1-23.

Nguyen, L.T.C. and Gu, Y. (2013). Strategy-based instruction: A learner-focused approach to developing learner autonomy. Language Teaching Research, 17(1), 9-30. http:/ / dx.doi.org/10.1177/1362168812457528.

Nisbet, J. and Shucksmith, J. (1986). Learning Strategies. Routledge ve Kegan Paul, London, Boston and Henley.

O'Malley, J.M. and Chamot, A.U. (1990). Learning strategies in second language acquisition. Cambridge University Press, Cambridge. https:// doi.org/10.1017/CBO9781139524490

O’Malley, J.M., Chamot, A.U., Stewner-Manzanares, G., Kupper, L. and Russo, R.P. (1985). Learning strategies used by beginning and intermediate ESL students. Language Learning, 35(1), 21-46. https:/ / doi.org/10.1111/j.14671770.1985.tb01013.x

Ocak, G. ve Akkaş Baysal, E. (2019). Öğrenme ortamında eylem araştırması kullanan öğretmenlerin eylem araştırması hakkındaki görüşleri. Mehmet Akif Ersoy Üniversitesi Ĕ̈itim Fakültesi Dergisi, 47, 283-307.

Ocak, G. ve Olur, B. (2019). Bilimsel Araştırma Süreci: Giriş. (Ed.) G. Ocak, Eğitimde bilimsel araştırma yöntemleri. Ankara, Pegem Akademi. https:/ / doi.org/10.14527/9786052419649.01

Oxford, R.L. (1990). Language learning strategies: what every teacher should know. Newbury House, New York.

Patton, M.Q. (1987). Qualitative research and evaluation methods. Thousand Oaks, CA: Sage. 
Rao, Z. (2007). Training in brainstorming and developing writing skills. ELT Journal, 61, 100-105. https:// doi.org/10.1093/elt/ccm002

Raoofi, S., Binandeh, M. and Rahmani, S. (2017). An investigation into writing strategies and writing proficiency of university students. Journal of Language Teaching and Research, 8, 191-198. https:// doi.org/10.17507/jltr.0801.24

Ridhuan, M. and Lim, A.T. (2009). The writing strategies used by engineering ESL Malay learners. Conference of the International Journal of Arts ve Sciences. Retrieved December 27, 2010, from http:/ / eprints.utp.edu.my/2035/.

Rubin, J. (1975). What the "good language learner" can teach us. TESOL Quarterly, 9, 41-51. https:// doi.org/10.2307/3586011

Rubin, J. (1987). Learner strategies: theoretical assumptions, research history and typology. In Wenden, A. and Rubin, J. (Eds.) Learner strategies in language learning. Prentice Hall International, Hemel Hempstead.

Sabria, O. (2016). Language learning strategies use in teaching the writing skill for EFL Algerian learners. Arab World English Journal (AWEJ), 7(3), 479-486. https://doi.org/10.24093/awej/vol7no3.33

Sandelowski, M. and Barroso, J. (2002). Finding the findings in qualitative studies. Journal of Nursing Scholarship, 34, 213-219. https:/ / doi.org/10.1111/j.1547-5069.2002.00213.x

Sasaki, M. (2007). Effects of study-abroad experiences on efl writers: a multiple-data analysis. The Modern Language Journal, 91(4), 602-620. http:/ / dx.doi.org/10.1111/j.1540-4781.2007.00625.x

Schoen, S.F. and Nolen, J. (2004). Action research: decreasing acting-out behavior and increasing learning. Teaching Exceptional Children, 37(1), 26-29. https:/ / doi.org/10.1177/004005990403700103

Stern, H.H. (1975). What can we learn from the good language learner?. Canadian Modern Language Review, 31(2), 304-318. https:/ / doi.org/10.3138/cmlr.31.4.304

Watts-Taffe, S. and Truscott, D.M. (2000). Using what we know about language and literacy development for ESL students in the mainstream classroom. Language Arts, 77, 258-265.

Weigle, S.C. (2005). Second language writing expertise. In K. Johnson (Ed.), Expertise in second language learning and teaching (pp. 128-149). NY: Palgrave Macmillan, Basingstoke, New York. https:/ / doi.org/10.1057/9780230523470_7

Weinstein, C. and Mayer, R. (1986). The Teaching of Learning Strategies. In M. C. Wittrock (Ed.), Handbook of Research on Teaching (315-327). Macmillan, New York.

Wenden, A.L. (1987). Incorporating learner training in the classroom. In Wenden, A. and Rubin, J. (eds.), Learner strategies in language learning, (159-167). NJ: Prentice Hall, Englewood Cliffs.

Wong, A.T. (2005). Writers' mental representations of the intended audience and of the rhetorical purpose for writing and the strategies that they employed when they composed. System, 33(1), 29-47. https:/ / doi.org/10.1016/j.system.2004.06.009 
Yusuf, Q., Jusoh, Z. and Yusuf, Y.Q. (2019). Cooperative learning strategies to enhance writing skills among second language learners. International Journal of Instruction, 12(1), 1399- 1412. https:/ / doi.org/10.29333/iji.2019.12189a

\section{Summary}

\section{Introduction}

Along with cognitive theories and approaches where the student is at the center, learner-centered designs have emerged in foreign language teaching. In parallel with this change, individual characteristics of learners have gained greater importance. Curiosity and interest in how students become successful and the reasons for their failure have been increasing. Language learning strategies are one of the factors that significantly affect students' success and teaching-learning situations. Language learning strategies, the most often preferred strategies by learners and the characteristics of a good learner have been the subject of many research (Berry, 2007; Cohen, 1990; Nisbet ve Shucksmith, 1986; O'Malley ve Chamot, 1990; Oxford, 1990; Rubin, 1987).

The fact that individuals who learn languages have problems in writing skills is largely due to their poor thinking skills in the target language. Writing in the target language is perceivedas a complex and versatile phenomenon for many learners. Again, for most of the learners, writing in the target language is much more difficult than writing in their mother tongue. It has been emphasized by many researchers that using writing strategies in the target language improves writing skills (Sabria, 2016; Sasaki, 2007; Wong, 2005). In these studies, it is stated that there is a positive relationship between the writing strategies used in the target language and the writing skills of the learners, and the competencies of the learners who use more writing strategies improve.

In this context, it is aimed to eliminate the problems faced by the 9th grade Anatolian High School students in their English writing skills by teaching them how to use language learning strategies in terms of writing skill. In the present research, the answers of the following research questions will be sought:

1-What are the positive effects of using writing skills language learning strategies in English writing activities?

2-What are the negative aspects of using writing skills language learning strategies in English writing activities?

3-What is the contribution of writing skills language learning strategies to the development of students' writing skills?

\section{Method}

The research has been conducted with the action research method, which is one of the qualitative research methods. The study group of the research was determined by purposeful sampling method. The study group of the research consists of 38 students who were 9th grade students in a high school located in Afyonkarahisar city center in the 2018-2019 academic year. Qualitative data collection tools were employed. The data collection process of the research was carried out in two stages. The first step of collecting data related to the research was completed during the implementation of the action plans. In this period, observation form and researcher diary were used as 
data collection tools. The second step of collecting data for the research was to conduct interviews. At this stage, the data were collected through semi-structured interview forms. Descriptive analysis was administered by coding the data obtained in the research in accordance with the themes and sub-themes determined before the interviews. In this study, validity and reliability were achieved by using appropriate data collection and analysis methods, and by ensuring alignment among the research questions, the data collection and analysis techniques.

Within the scope of the research, three different activities including writing skills, language learning strategies and writing activities were carried out with three different action plans.

\section{Results}

In this study that writing skills language learning strategies were tried to be implemented in prepared action plans, it was aimed to eliminate the problems encountered in English writing skills. In the research, the data were collected in two stages, therefore the research findings were presented in two stages. In the presentation of the data gathered in the first stage, observation notes in the process of implementation of the action plan and sample statements from the diary of the researcher-practitioner are included. In the second stage, the data obtained from interviews are presented.

\section{Conclusion and Discussion}

The ability to write in English is very important to start language learning in the language learning process. This significance stems from the use of writing skills and grammatical structures of the target language and vocabulary. In this study, it is aimed to teach students strategies related to writing skills, one of skill-based language learning strategies, and to improve their writing skills. Students need time and interaction with language to improve their writing skills. For this reason, the study was carried out not with a single action plan or a single activity, but with three action plans and more activities. After the teaching process in which a three-week writing strategies action plans were included, the writing products of the students before the teaching of the strategy and the writing products in the teaching process were compared in order. The paragraphs of the students before learning the strategy use were very short and transitions between sentences were not convenient and fluent. Since the week they started using the strategies, the students produced texts composed of paragraphs. In the first week, while paragraphs were very short, they were quite rich in terms of words and sentences in the second and last week. This demonstrates that strategy teaching contributed to the development of students' ability to write more structured and meaningful paragraphs. The students wrote the first sentence of the paragraph, which is one of the most important features of a wellstructured paragraph, with a great focus and used expressions that gave clues about the content of the paragraph. Furthermore, students learned how to prepare a draft before creating clear and understandable paragraphs. 


\section{Pedagogical Implications}

Considering the results of the study, it is clear that more studies about other skills such as speaking, reading and listening are needed. Among the limitations of the study, it can be stated that it is a qualitative study. To support the findings and results of the study a quantiative study can be conducted with larger samples.

\section{Araştırmanın Etik İzinleri}

Yapılan bu çalışmada "Yükseköğretim Kurumları Bilimsel Araştırma ve Yayın Etiği Yönergesi" kapsamında uyulması belirtilen tüm kurallara uyulmuştur. Yönergenin ikinci bölümü olan "Bilimsel Araştırma ve Yayın Etiğine Aykırı Eylemler" başlı̆̆ı altında belirtilen eylemlerden hiçbiri gerçekleştirilmemiştir.

Etik kurul izin bilgileri

Etik değerlendirmeyi yapan kurul adi = Afyon Kocatepe Üniversitesi Sosyal ve Beşeri Bilimler Bilimsel Araştırma ve Yayın Etiği Kurulu

Etik değerlendirme kararının tarihi=16.10.2017

Etik değerlendirme belgesi sayı numarası=2017/05

\section{Authors' Biodata / Yazar Bilgileri}

Gürbüz OCAK Afyon Kocatepe Üniversitesi Eğitim Programları ve Öğretim Anabilim dalında Prof. Dr. olarak görev yapmaktadır.

Gürbüz Ocak works as a Prof. Dr. at Afyon Kocatepe University, Faculty of Education, Department of Curriculum and Instruction.

Emine AKKAŞ BAYSAL Afyon Kocatepe Üniversitesi Sandıklı Uygulamalı Bilimler Yüksekokulu'nda Dr. Öğr. Üyesi olarak görev yapmaktadır.

Emine Akkaş Baysal works as an Asst. Prof. at Afyon Kocatepe University, Sandiklı School of Applied Disciplines. 